\title{
Sedimentary sources of the mud-breccia and mud volcanic activity in the Western Alboran Basin
}

\author{
G. Gennari ${ }^{\text {a,* }}$, S. Spezzaferri ${ }^{\text {a }}$, M.C. Comas ${ }^{\text {b }}$, A. Rüggeberg ${ }^{\text {a,c,d }}{ }^{\text {, C. Lopez-Rodriguez }}{ }^{\text {b }}$, L.M. Pinheiro ${ }^{\text {e }}$ \\ a University of Fribourg, Department of Geosciences, Earth Sciences, Ch. du Musée 6, 1700 Fribourg, Switzerland \\ ${ }^{\mathrm{b}}$ Instituto Andaluz de Ciencias de la Tierra (CSIC-UGR), Avenida de las Palmeras 4, 18100 Armilla (GR), Spain \\ c Renard Centre of Marine Geology, Gent University, Krijgslaan 281-S8, B-9000 Gent, Belgium \\ d GEOMAR-Hemholtz Centre for Ocean Research Kiel, Wischhofstrasse 1-3, D-24148 Kiel, Germany \\ e Departamento de Geociências and CESAM, Universidade de Aveiro, 3810-193 Aveiro, Portugal
}

\begin{abstract}
During the TTR-17 Leg 1 cruise in the West Alboran Basin, gravity cores were acquired from three mud volcanoes (MVs): Dhaka, Carmen and the recently discovered Maya. This paper presents micropaleontological and radiocarbon dating results from the three mud volcanoes, using cores containing mud breccias overlain by and interbedded with hemipelagic sediments. At Dhaka MV, the mud-breccia matrix contains very rare Holocene planktonic foraminifera associated with abundant reworked specimens of mixed Late Cretaceous to Mio-Pliocene age. At Carmen MV, the reworked assemblage is dominated by Miocene to Pliocene foraminifera occurring together with rare Late Cretaceous species while at Maya MV the mud-breccia matrix is characterized by the dominance of Santonian-Maastrichtian forms, with subordinate Tertiary species. Shallow-water benthic foraminifera such as Ammonia spp. and Elphidium spp. are generally rare and randomly distributed, but present at all studied sites. Based on these results, we suggest that the main sediment source of the mud-breccia extruded at Dhaka, Carmen and Maya MVs is possibly the lowermost overpressured olistostromic Unit VI (Aquitanian?-Burdigalian). Differences in the micropaleontological composition of the mud-breccia matrix at different sites are most likely due to differences in the main source layer and in the plumbing systems underneath the MVs. Radiocarbon dating of hemipelagic sediments associated to the mud-breccia allowed to define the age of the latest extrusion activities $(>0.27 \mathrm{ka}$ to $>15.6 \mathrm{ka}$ $\mathrm{BP}$ ), which seem to be episodic, short-lived and recurrent over thousands of years.
\end{abstract}

\section{Introduction}

Mud volcanism and diapirism include both subaerial and subaqueous manifestations (Chapman, 1974) and are a widespread phenomenon in many areas of the world's oceans such as the Mediterranean Sea, the Gulf of Cadiz, the Black Sea, Barbados, Makran, Aleutians, and the Caspian Sea. They occur on both active and passive margins, but are more abundant in convergent tectonic settings (reviews in Dimitrov, 2002; Kopf, 2002).

Mud volcanoes (MVs) are prominent surface or seafloor features resulting from the upward migration of hydrocarbon-rich fluids and solids generated by pore-fluid overpressures in clay-rich formations at depth (e.g., Dimitrov, 2002; Kopf, 2002; Praeg et al., 2009). Their surface expression is the result of the progressive accumulation of extruded mud-breccia, a semi-liquid, clayey matrix containing various

\footnotetext{
* Corresponding author.

E-mail addresses: giordana.gennari@gmail.com (G. Gennari),

silvia.spezzaferri@unifr.ch (S. Spezzaferri), Andres.rueggeberg@unifr.ch,

Andres.Ruggeberg@UGent.be, arueggeberg@geomar.de (A. Rüggeberg),

mcomas@ugr.es, carmina@ugr.es (C. Lopez-Rodriguez), lmp@ua.pt (L.M. Pinheiro).
}

amounts of heterogenic rock fragments and clasts, derived from the geological section through which the mud ascends, which are eventually incorporated into the matrix (Cita et al., 1981; Staffini et al., 1993; Dimitrov, 2002; Kopf, 2002).

Mud volcanoes can root in sedimentary deposits that are several kilometers below the seafloor (Higgins and Saunders, 1974; Fowler et al., 2000; Aslan et al., 2001) and can thus be considered as 'windows' into the sedimentary basins that reveal the composition of deep sediments. However, fluids rising through deep-rooted feeding channels may be also stored at intermediate to shallow-depth mud chambers and be remobilized via sub-surface interconnected plumbing systems (Deville et al., 2003, 2010; Praeg et al., 2003, 2009; Mazzini et al., 2009).

In the Eastern Mediterranean, mud volcanoes (MVs) were first discovered west of Crete (Cita et al., 1981) on the Mediterranean Ridge, an accretionary prism with double vergence developed in a subduction zone (e.g., Camerlenghi et al., 1995; Premoli Silva et al., 1996). Since then, intensive investigation mostly carried out in the framework of the Training Through Research Program (TTR) has resulted in the discovery of numerous new MVs on the crest of the Mediterranean Ridge (Limonov et al., 1996). Drilling during ODP Leg 
160 proved that mud volcanoes in the northern margin of the Mediterranean Ridge were active since at least $1 \mathrm{Ma}$ (Robertson and Ocean Drilling Program Leg 160 Scientific Party, 1996). Mud volcanoes active over the last $3 \mathrm{Ma}$ were recently discovered along the off-shore Calabrian Arc, at the tip of the Apenninic-Maghrebide accretionary system (Praeg et al., 2009). Occurrence of mud volcanism and diapirism in the Eastern Mediterranean is also recorded in an extensional setting: the Nile Deep Sea Fan (e.g., Loncke et al., 2004; Dupré et al., 2007)

Mud volcanoes are well known west of the Gibraltar Strait, in the Gulf of Cadiz, along the Atlantic counterpart of the Alboran Basin in the Gibraltar Arc System (GAS; e.g., Pinheiro et al., 2003; Somoza et al., 2003; Fernández-Puga et al., 2007) where the related phenomena such as cold seepage, pockmarks, hydrocarbon venting, methanederived authigenic carbonates and gas hydrates have been investigated since 1996 (Baraza and Ercilla, 1996; Baraza et al., 1999; Ivanov et al., 2000, 2001; Kenyon et al., 2000; Somoza et al., 2000, 2003; Gardner, 2001; Mazurenko et al., 2002; Pinheiro et al., 2003, 2006; Magalhães et al., 2012). Their origin is associated with recent compressive tectonics on shale and salt deposits of the olistostrome/accretionary complex units, emplaced as an allochthonous unit in the Late Miocene as a result of Africa- Eurasia convergence (Maldonado et al., 1999; Somoza et al., 2003).

In the Western Mediterranean, MVs are relatively scarce features (e.g., Sautkin et al., 2003), and in particular, in the Alboran Sea, they are related to mud diapirs and active sediment and fluid flow in a back-arc basin setting (Talukder, 2003; Talukder et al., 2003; Comas et al., 2010). Their existence in this basin was first documented in 1999 during the TTR-9 Leg 2 along the Moroccan margin. Further surveys carried out from 2002 to 2008 (TTR-12, 14, 17) revealed the existence of several mud volcanoes, pockmarks and seepage-related structures on both the Spanish and the Moroccan margin of the West Alboran Basin. Among them, the mud volcano named Carmen, discovered in 2004 during TTR-14, was proved to be active (Fig. 1; Comas et al., 2000, 2003a, 2003b, 2006, 2010; Kenyon et al., 2000, 2003, 2006; Sautkin et al., 2003; Talukder et al., 2003; Blinova et al., 2011).
During the TTR-17 Leg 1 cruise, the mud volcano fields of the West Alboran Basin (Iberian and Moroccan margins) were revisited to core some of the MVs previously known and to explore the occurrence of new MVs and related features in the region (Fig. 1). As a result of this extensive survey, a new small mud volcano, named Maya, was discovered and cored for the first time (Blinova et al., 2011; Margreth et al., 2011).

Previous works on the Mud Diapiric Province focused on the MV structures and their relationship with shale diapirs (Sautkin et al., 2003; Talukder et al., 2003; Somoza et al., 2012), as well as on the identification of the source layer (Sautkin et al., 2003). Recently, the study of fluid discharged at different seep sites in the area proved that Carmen MV is presently active (Blinova et al., 2011).

In this research, we investigate the micropaleontology of three gravity cores retrieved from Dhaka, Carmen and Maya MVs during the TTR-17 cruise (Fig. 2). The cores contain mud breccias interbedded with or overlaid by hemipelagic sediments. Following previous studies on mud volcanoes (e.g., Staffini et al., 1993; Premoli Silva et al., 1996, Sautkin et al., 2003), this study focuses on the mud-breccia matrix, because it is considered as more representative of the whole breccia-framework, in which coarser clasts are often of difficult interpretation and attribution, due to the fact that they may correspond to remobilization of olistostromic allochthonous bodies. The aims of our study are:

1. To investigate the stratigraphic succession underlying the mud volcanoes;

2. To identify the source of the extruded mud-breccias;

3. To date recent extrusive episodes.

\section{Geological setting}

The Alboran Sea, located behind the Gibraltar Arc, is the westernmost basin of the Mediterranean Sea. Its northern boundary is the Betic Cordillera (Southern Spain) and its southern boundary is the

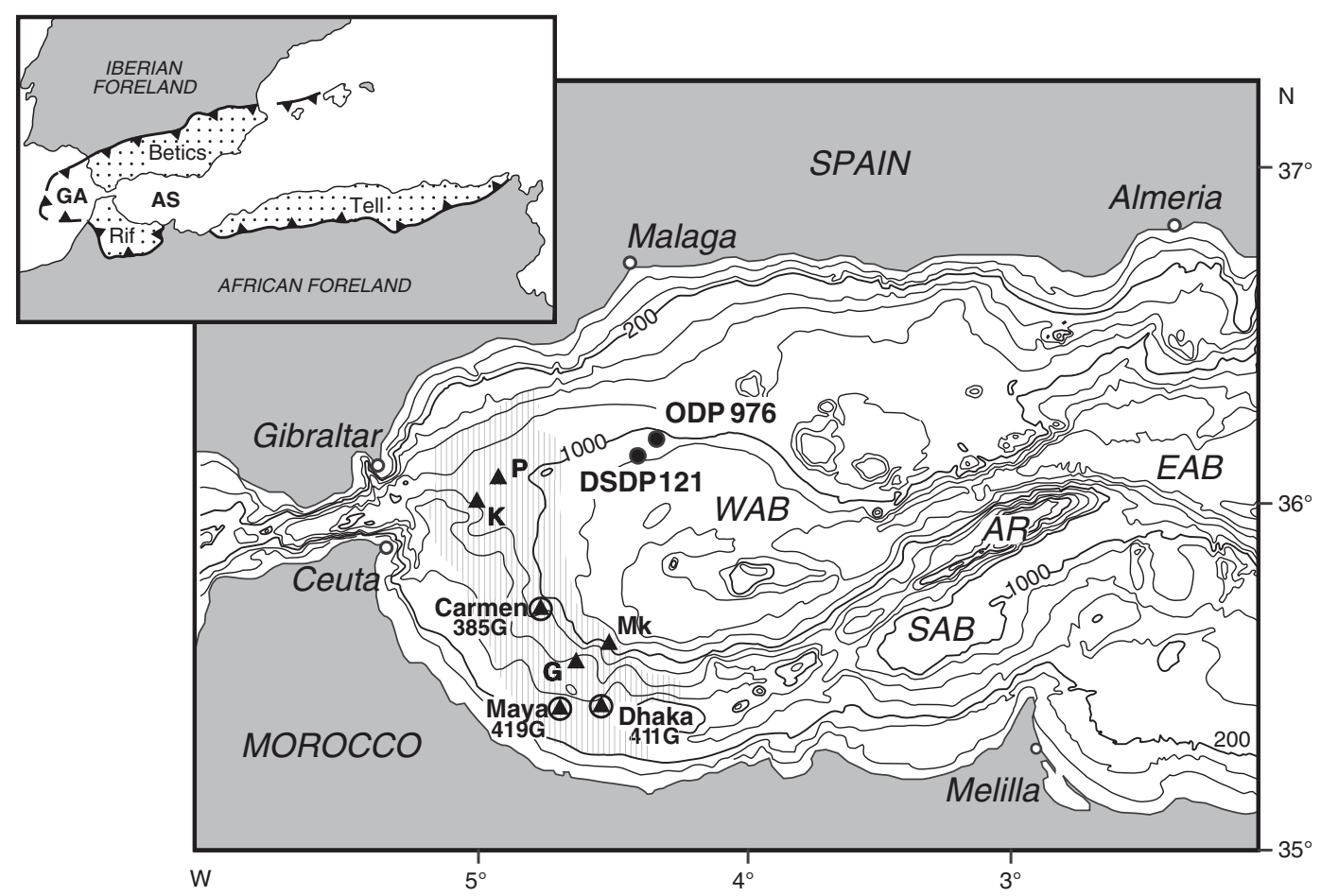

Fig. 1. Location map of the studied cores in the Alboran Sea (GA: Gibraltar Arc; AS: Alboran Sea; WAB, SAB, EAB: Western, Southern, Eastern Alboran Sea; AR: Alboran Ridge; Vertical shaded area: Mud Diapiric Province). Solid triangles show locations of mud volcanoes (P: Perejil; K: Kalinin, G: Granada; Mk: Marrakech). Empty circles indicate coring sites. Solid circles indicate location of DSDP Site 121 and ODP Site 976. (Modified from Comas et al., 1999). 
DHAKA MV

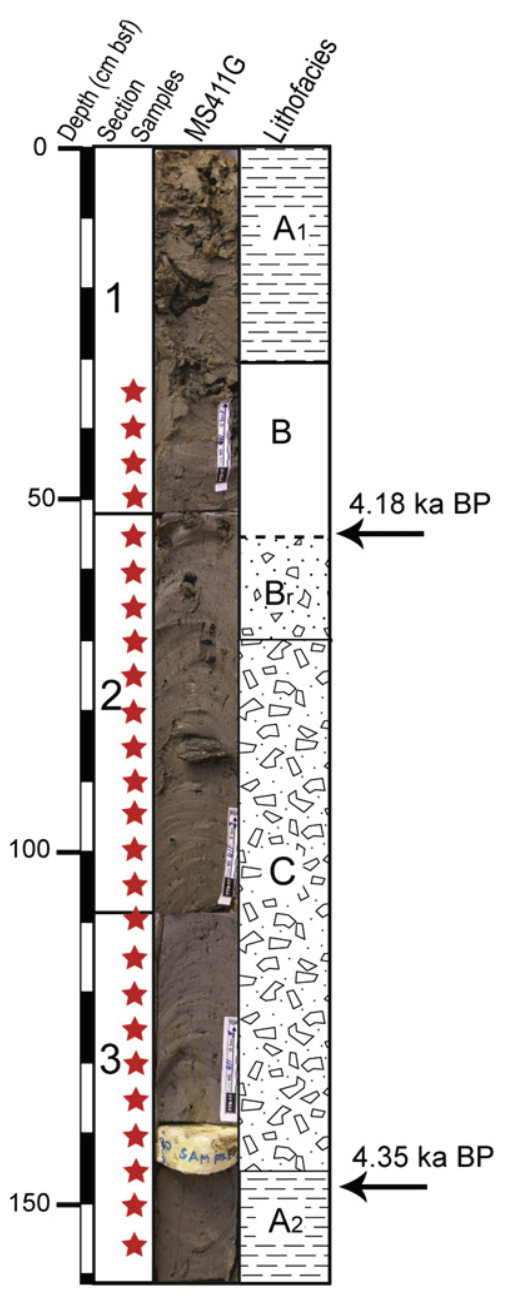

MAYA MV

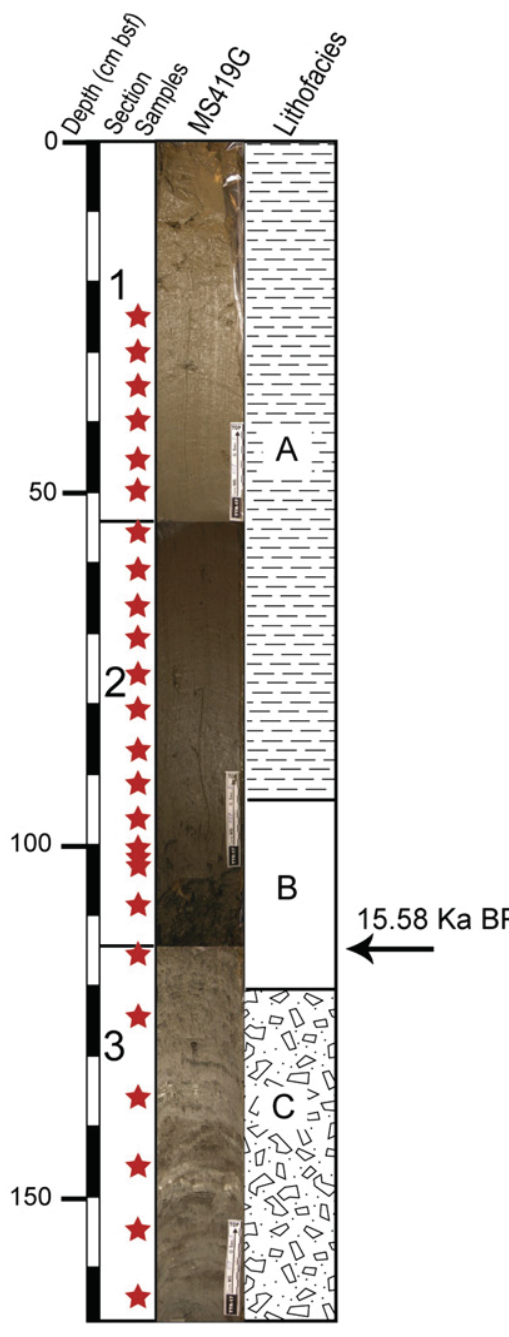

CARMEN MV

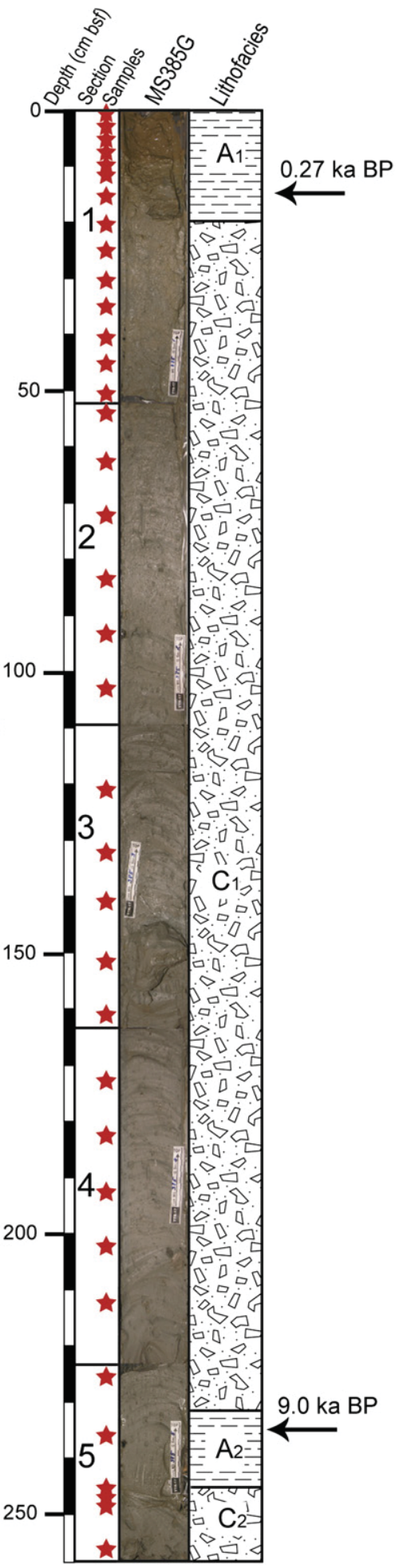

Fig. 2. Photographs of the studied cores together with their lithologic logs and $\mathrm{AMS}-{ }^{14} \mathrm{C}$ age dating.

Rif and Tell Mountains in North Africa (Comas et al., 1999). It is part of the Gibraltar Arc System (GAS) and corresponds to a remaining submerged part of the Miocene Alboran Basin (Comas et al., 1999).

The geodynamic behavior of the GAS is the consequence of its position at the boundary between two plates - Africa and Eurasia - that have had variable directions of relative motion since the late Cretaceous.
Plate-tectonics restoration suggests that this segment of the AfricanEurasian plate boundary experienced about $200 \mathrm{~km}$ of roughly $\mathrm{N}-\mathrm{S}$ oriented convergence between the mid-Oligocene and late Miocene, followed by about $50 \mathrm{~km}$ of NNW directed oblique convergence since the late Miocene (Dewey et al., 1989). Active tectonics related to plate convergence continues to influence the development of the GAS to 


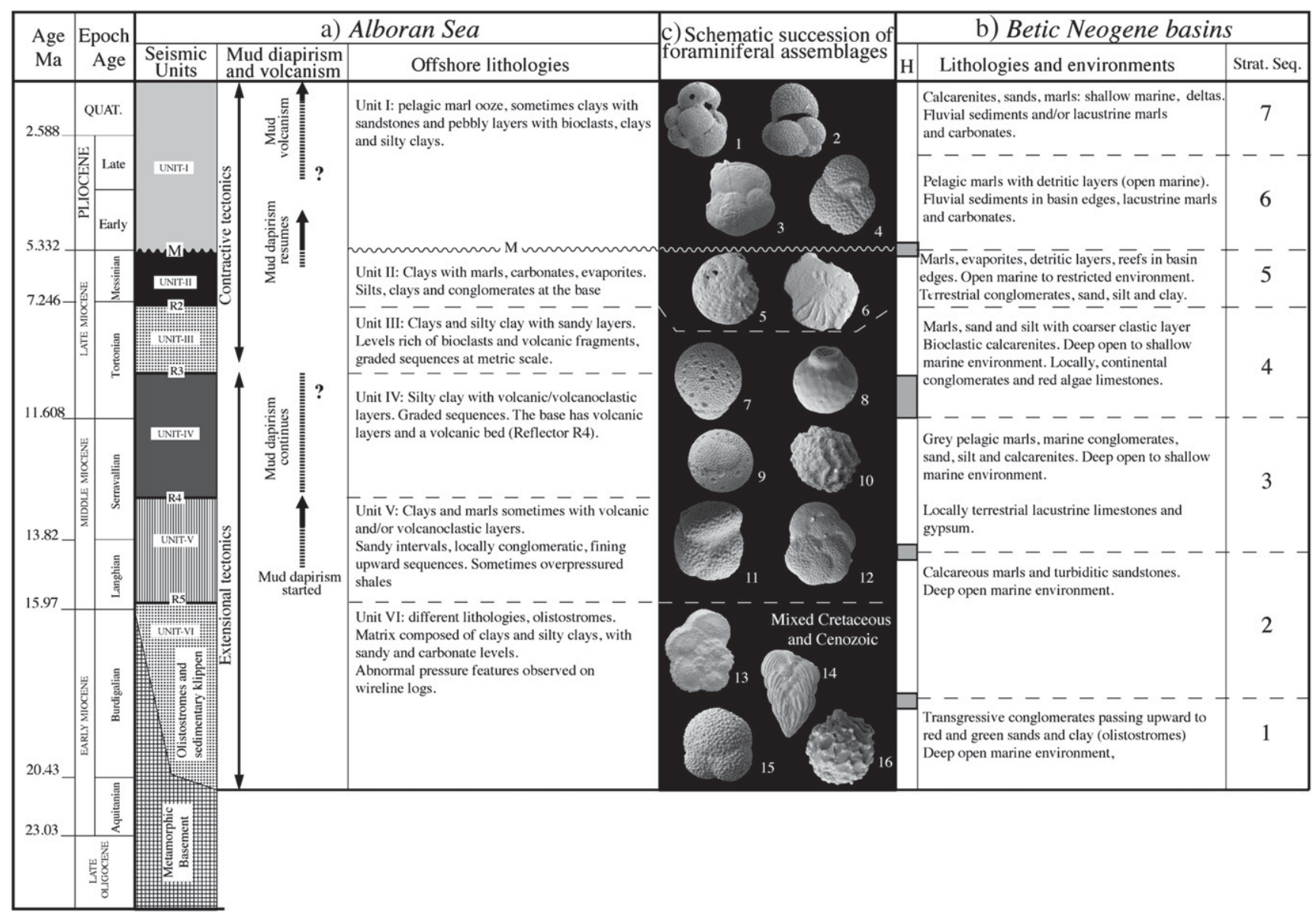

Fig. 3. Correlation of the Alboran Sea seismic units (a) with the main sedimentary sequences documented in the Betic Neogene basins (b), together with a short description of sedimentary environments (modified from a) Jurado and Comas, 1992; Comas et al., 1996; b) Rodríguez-Fernández et al., 1999); M: Messinian unconformity; H: Hiatuses (grey rectangles; correlative unconformities are not shown); Strat. Seq: Stratigraphic Sequences of Rodríguez-Fernández et al. (1999). c) A schematic succession of the main foraminiferal assemblages based on the present study, according to age and/or environmental marker species is also given: $1=$ Globigerina cariacoensis (pelagic, Quaternary); $2=$ Beella praedigitata (pelagic, Quaternary); $3=$ Globorotalia margaritae (pelagic, Pliocene); $4=$ Zeaglobigerina nepenthes (pelagic, Pliocene), $5=$ Elphidium sp. (shallow water): $6=$ Amphistegina sp. (shallow water and/or reef); $7,9=$ Praeorbulina glomerosa (pelagic, Early Miocene); 8 = Bolboforma capsula (pelagic, Late Miocene); 10 = Bolboforma subfragoris (pelagic, Late Miocene); $11=$ Globoquadrina dehiscens (pelagic, Late Oligocene-Late Miocene); 12 = Globorotalia peripheronda (pelagic, Early-Middle Miocene); 13 = Globotruncana hilli (pelagic, Maastrichtian): $14=$ Pseudoguembelina palpebra (pelagic, Maastrichtian); 15 = Praeorbulina glomerosa (pelagic, Early-Middle Miocene); 16 = Bolboforma spinosa (pelagic, Lower Miocene).

the present, and there is evidence from seismicity patterns that the Alboran Basin is still deforming in response to present-day plate tectonics (e.g., Faccenna et al., 2004; Frizon de Lamotte et al., 2006; Fernández-Ibáñez et al., 2007, and references therein).

The Alboran Basin originated in the Early to Middle Miocene from extension and subsidence related to crustal thinning, which took place coeval with crustal thickening in the peripheral thrust belt (e.g., Comas et al., 1992, 1999; García-Dueñas et al., 1992 and references therein).

The West Alboran basin contains a Miocene to Quaternary sedimentary succession up to $9 \mathrm{~km}$ thick filling grabens and half-grabens between basement highs as indicated by seismic reflection data (Comas et al., 1992, 1996; Martínez del Olmo and Comas, 2008) Based on multichannel seismic surveys, wire line log interpretation and well data from commercial holes and from DSDP Site 121, six seismic stratigraphic units bounded by major reflectors corresponding to regional unconformities were recognized in the sedimentary cover of the basin (Unit VI to I; Comas et al., 1992; Jurado and Comas, 1992; Fig. 3, a) Alboran Sea). Scientific drilling during ODP leg 161 (e.g., Site 976; Comas et al., 1996, 1999) provided further significant information on sediment lithology and ages. According to these data, the oldest sediments that directly overlay the metamorphic basement are latest Aquitanian?-Burdigalian marine deposits consisting of clastic material and under-compacted shales, containing olistostromes (Unit VI). Unit
VI has been drilled only at Alboran A-1 well offshore southern Spain. Based on the seismic character and geometries displayed, this unit has been interpreted as a syn-rift deposit and has been correlated to inland complexes composed of clays and detrital deposits containing olistostromes (e.g., Rodríguez-Fernández et al., 1999; Fig. 3, b) Betic Neogene basins). Unit V (Langhian-early Serravallian) is composed by clays and marls interbedded by volcanic and volcanoclastic deposits. Sandy intervals and fining-upward graded sequences are also present. Very similar lithologies characterize also Unit IV (Serravallian-early Tortonian), whose basal boundary is constituted by a volcanic bed. Sediments from seismic Unit III (early-late Tortonian) consist in clays and silty clays with sandstone interbeds. The Messinian deposits (seismic Unit II) consist of marine siliciclastic or shallow carbonate facies, with occasional gypsum and anhydrite intervals. Pliocene to Quaternary sediments (Unit I) are mainly fine-grained distal marls and clays, with rare interbedded sandstones (Comas et al., 1992, 1999; Jurado and Comas, 1992).

In Unit VI and lowermost Unit V, physical properties typical of undercompacted clays have been recognized in well log parameters (wells Alboran A-1 and Andalucia G-1; Jurado and Comas, 1992). According to seismic reflection evidence, mud volcanoes in the "Mud Diapir Province" of the West Alboran basin are rooted in these overpressured clays (Unit VI of Comas et al., 1992, 1999; Jurado and Comas, 1992; Martínez del Olmo and Comas, 2008). 


\section{Materials and methods}

The three studied cores were obtained with a 6-m-long gravity corer with a diameter of $15 \mathrm{~cm}$ during the R/V Professor Logachev TTR-17 cruise.

The Dhaka and Maya mud volcanoes are located in the Southern MV Field (Fig. 1, Table 1). The studied gravity cores were retrieved from the top of the volcanoes at a water depth of $370 \mathrm{~m}$ on the Dhaka MV (MS411G) and of $410 \mathrm{~m}$ on the Maya MV (MS419G).

Carmen MV is located in the northernmost part of the Southern MV Field (Fig. 1, Table 1). Core MS385G was retrieved from the flank of Carmen MV, at a water depth of $806 \mathrm{~m}$.

\subsection{Micropaleontological analysis}

Samples from pelagic/hemipelagic sediments and mud-breccia matrix were selected and analyzed to evaluate the thickness of the breccia layers and to assess the age of the source sediments involved in the mud-breccia extrusion. Planktonic foraminifera were studied in eightysix samples from Dhaka, Maya and Carmen MVs. Fifty-three of these samples were from the mud-breccia layers. They were soaked in diluted hydrogen peroxide and then washed under running water with $>250$, 250-125 and 125-40 $\mu \mathrm{m}$ mesh sieves. The obtained three size fractions were dried on a hot plate and studied under a binocular microscope. Abundances of planktonic foraminifera were based on the number of specimens per field of view (s/fov) and defined as follow: very rare, $1 \mathrm{~s} /$ fov; rare, $2 \mathrm{~s} /$ fov; rare to common, $3 \mathrm{~s} /$ fov; common, $4 \mathrm{~s} /$ fov; abundant: $5 \mathrm{~s} /$ fov.

\subsection{AMS $-{ }^{14} \mathrm{C}$ dating}

The age assessment of mud volcanic activity at the three studied MVs is based on five Accelerator Mass Spectrometry (AMS) ${ }^{14} \mathrm{C}$ age determination (Table 2; Fig. 2) obtained at the Leibniz Laboratory for Age Determinations and Isotope Research of the University of Kiel. For each of the studied cores, sediment samples were taken from the hemipelagic layers, immediately above and below (Dhaka and Carmen) the mudbreccia interval. Radiocarbon data from Dhaka and Maya MVs have been recently published (Margreth et al., 2011); data from Carmen MV (15 cm and $235 \mathrm{~cm}$ b.s.f.) are presented in this study (Table 2). For each sample, at least $5 \mathrm{mg}$ of planktonic foraminifera (Globorotalia inflata or mixed planktonic foraminifera) were handpicked to provide 0.2 to $1.2 \mathrm{mg}$ of carbonate material. The organic material was removed in an ultrasonic bath with $15 \% \mathrm{H}_{2} \mathrm{O}_{2}$. The hydrolysis of the residual pure calcite was obtained at $90{ }^{\circ} \mathrm{C}$ with $100 \%$ orthophosphoric acid. The carbon dioxide was converted to graphite with hydrogen on an iron catalyst. The iron-graphite mixture was measured on the Accelerator Mass Spectrometer (AMS). A reservoir correction of 400 years (Siani et al., 2000) was subtracted from the obtained radiocarbon conventional ages, which were calibrated using the program CALIB 5 (Stuiver and Reimer, 1993).

\section{Results}

\subsection{Core description}

Core MS411G (Dhaka MV) retrieved $162 \mathrm{~cm}$ of sediments (Fig. 2). The first $2 \mathrm{~cm}$ consist of brown, structureless and water-saturated

Table 1

Location, water depth and length of the studied core.

\begin{tabular}{lllll}
\hline Gravity core & Site & Position & $\begin{array}{l}\text { Length } \\
(\mathrm{cm})\end{array}$ & $\begin{array}{l}\text { Water depth } \\
(\mathrm{m})\end{array}$ \\
\hline TTR-17MS411G & Dhaka MV & $35^{\circ} 25.43 \mathrm{~N} ; 04^{\circ} 31.89 \mathrm{~W}$ & 162 & 370 \\
TTR-17MS419G & Maya MV & $35^{\circ} 27.11 \mathrm{~N} ; 04^{\circ} 37.14 \mathrm{~W}$ & 167 & 410 \\
TTR-17MS385G & Carmen MV & $35^{\circ} 43.31 \mathrm{~N} ; 04^{\circ} 44.06 \mathrm{~W}$ & 258 & 806 \\
\hline
\end{tabular}

marls with abundant foraminifera and down to $30 \mathrm{~cm}$, sediments are composed of hemipelagic marls (lithofacies $A_{1}$ ). From 30 to $55 \mathrm{~cm}$ b.s.f. (lithofacies B), they contain abundant foraminifera and cold-water coral fragments (Margreth et al., 2011). Lithofacies $B_{r}$ represents a layer with abundant mixing between elements from the hemipelagic sediments and the mud-breccia (55 to $70 \mathrm{~cm}$ b.s.f.). The mud-breccia (lithofacies C) is observed from $70 \mathrm{~cm}$ to about $145 \mathrm{~cm}$ b.s.f. It consists of a dark-grey, structureless clay (matrix) and marlstone- or semilithified marly-clasts up to more than $10 \mathrm{~cm}$ in diameter. The matrix contains planktonic foraminifera of different ages together with shallow and deep-water benthic foraminifera. Signs of oxidation and bioturbation are observed at $128 \mathrm{~cm}$. At $150 \mathrm{~cm}$ b.s.f. sediments are represented again by hemipelagic marls (lithofacies $\mathrm{A}_{2}$ ).

Core MS419G (Maya MV) has $165 \mathrm{~cm}$ of recovery (Fig. 2). From the core top down to $95 \mathrm{~cm}$ b.s.f., sediments consist of grey clay, soupy and water-saturated in the uppermost $20 \mathrm{~cm}$, with foraminiferal burrows and abundant foraminifera (lithofacies $\mathrm{A}_{1}$ ). Scattered coral fragments are present in the uppermost $20 \mathrm{~cm}$. From $95 \mathrm{~cm}$ to $125 \mathrm{~cm}$ b.s.f., the sediments contain foraminifera, shell fragments and cold-water coral fragments of lithofacies B (Margreth et al., 2011). The mud-breccia (lithofacies C) is present from $125 \mathrm{~cm}$ down to the core's bottom and consists of layered light-grey and grey to brownish-grey matrix with clasts less than $3 \mathrm{~cm}$ in diameter. As observed at Dhaka MV, the mud-breccia also contains a mixture of planktonic foraminifera of different ages together with shallow and deep-water benthic species.

Core MS385G (Carmen MV; Fig. 2) recovered $258 \mathrm{~cm}$ of sediments. The upper $20 \mathrm{~cm}$ consist of hemipelagic, brown, water-saturated clayey marls (Lithofacies $A_{1}$ ). The mud-breccia $\left(C_{1}\right.$ and $C_{2}$ ) is present from $20 \mathrm{~cm}$ down to the core's bottom, with a single hemipelagic intercalation (lithofacies $\mathrm{A}_{2}$ ) occurring at around $230-245 \mathrm{~cm}$ b.s.f. The mudbreccia consists of a structureless clayey matrix with randomly distributed clasts, highly variable in size $(1 \mathrm{~mm}$ to $10 \mathrm{~cm})$. Clasts present different lithologies: claystones, marlstones, siltstones, sandstones, tectonic breccia and conglomerates from very light in color to dark brown. A strong smell of $\mathrm{H}_{2} \mathrm{~S}$ was detected in the lower part of the core.

\subsection{Micropaleontology}

The results of the micropaleontological investigations are presented in Figs. 4 to 8. The identified different planktonic and benthic foraminiferal species, as well as Bolboforma, are listed in Appendix A. Fig. 9 shows the stratigraphical distribution of significant species identified in the studied samples. Cretaceous biostratigraphy follows the scheme of Premoli Silva and Verga (2004), Paleogene biostratigraphies are from Spezzaferri (1994), Premoli Silva et al. (2003), and Pearson et al. (2006). For the Neogene the schemes of Kennett and Srinivasan (1983), Iaccarino (1985, 2002), Sprovieri et al. (2002), and were applied.

The planktonic foraminiferal assemblages from the three MVs encompass a wide stratigraphic range and are composed by a mixture of late Cretaceous to Holocene species. Various degrees of mixing of fossil and recent species are observed throughout the cores. Samples from the mud breccias always contain rare quaternary species while samples from the hemipelagic layers are often characterized by the occurrence of fossil species. This may be due to 1 ) bioturbation by benthic macrofauna, 2) ejection of fine-grained material (i.e., extruded mud breccia and mobile hemipelagic sediments at the seafloor) into the water column during erupting activity and following redeposition, as proposed by Kohl and Roberts (1994), or 3) a combination of the two processes.

\subsubsection{Dhaka MV}

The planktonic foraminiferal assemblages from the upper part of the hemipelagic sequence (lithofacies $A_{1}$ ) of Dhaka MV are not represented in Fig. 4, as they contain only recent-Holocene forms without evidence of reworking. This part of the interval is dominated by planktonic species such as Globorotalia inflata, Globigerinoides spp., Turborotalita quinqueloba, Globigerinita glutinata and benthic foraminifera such as Globocassidulina 
Table 2

Results of AMS- ${ }^{14} \mathrm{C}$ dating. A reservoir age of 400 years was subtracted.

\begin{tabular}{llclcc}
\hline Lab code & Core & Depth & Material & ${ }^{14}$ C age (yr BP) & Calibrated age (yr BP) \\
\hline KIA 39076 & TTR-17MS411G & 55 & G. inflata & $4120 \pm 35$ & $4175 \pm 62$ \\
KIA 39078 & TTR-17MS411G & 150 & G. inflata & $4240 \pm 40$ & $4345 \pm 60$ \\
KIA 39200 & TTR-17MS419G & 115 & G. inflata & $13580 \pm 70$ & $15583 \pm 185$ \\
KIA 41267 & TTR-17MS385G & 15 & G. inflata & $620 \pm 20$ & $271 \pm 17$ \\
KIA 41268 & TTR-17MS385G & 235 & Mixed plankt. forams & $8405 \pm 45$ & Margreth et al. (2011) \\
\hline
\end{tabular}

subglobosa, Uvigerina mediterranea, Cassidulina carinata, and Bolivina difformis.

The underlying lithofacies B contains foraminiferal assemblages typical of cold-water coral ecosystems (Margreth et al., 2009, 2011). The planktonic foraminiferal fauna is dominated by Neogloboquadrina incompta together with Turborotalita quinqueloba and associated less abundant Globigerinita glutinata and Globigerina bulloides. In this interval, epifaunal-attached benthic foraminifera are more abundant than in the above hemipelagic sediments and are characterized by the occurrence of Discanomalina coronata, a species that was interpreted as a bio-indicator of living cold-water coral ecosystems along the Irish coasts in the Northeast Atlantic (Margreth et al., 2009), and Cibicidoides sp., Cibicidoides pachyderma, Angulogerina angulosa, and Lobatula lobatula (Margreth et al., 2011). In this part of the sedimentary sequence very rare reworked specimens consisting of Late Cretaceous (Campanian-Maastrichtian), and Eocene-Oligocene and MiocenePliocene long-range species are also present (Fig. 4). Lithofacies C, corresponding to the mud-breccia, contains very rare recent Holocene species and abundant specimens of mixed Late Cretaceous to MioPliocene age (Fig. 4). This interval contains also randomly distributed and rare shallow water benthic foraminifera such as Elphidium spp., Ammonia spp., Amphistegina sp. (Fig. 5). Hemipelagic sediments are also present in an interval at the bottom of the core $\left(A_{2}\right)$ and contain rare Late Cretaceous and very rare Miocene species (Fig. 4)

\subsubsection{Maya $M V$}

The upper hemipelagic interval at Maya MV (lithofacies A) is dominated by recent to Holocene planktonic foraminifera as observed at Dhaka MV, and in particular by G. inflata (Margreth et al., 2011). This interval contains also very rare Late Cretaceous and rarer long-range EoceneOligocene planktonic foraminifera. In Unit B, Cretaceous species are slightly more abundant; the accompanying assemblages include also rare long range Paleogene and Neogene species. Foraminiferal composition in this interval is similar to the cold-water coral-rich (lithofaceis B) interval observed at Dhaka MV. In the mud-breccia (lithofacies C) modern species are rare and reworked specimens strongly increase in abundance. Late Cretaceous (Campanian-Maastrichtian) species with subordinate Tertiary specimens dominate the planktonic assemblages (Fig. 6a). Shallow-water benthic foraminifera such as Elphidium spp. and Ammonia spp. are present but generally rare (Fig. 6b).

\subsubsection{Carmen $M V$}

The hemipelagic upper interval at Carmen MV (lithofacies $A_{1}$ ) is dominated by recent to Holocene planktonic foraminifera as observed at Dhaka and Maya MVs. In this interval very rare specimens of Miocene and Pliocene planktonic foraminifera are found (e.g., Paragloborotalia siakensis, P. acrostoma, Globorotalia miozea, and G. margaritae). Very rare Late Cretaceous specimens are randomly present and display poorer preservation than the major components of the assemblages and cannot be attributed to a specific time-interval.

Lithofacies B, containing coral fragments and the typical associated benthic foraminiferal assemblages, is absent at Carmen MV.

The mud breccia units are identified from 20 to $230 \mathrm{~cm}$ b.s.f. $\left(C_{1}\right)$ and from around $245 \mathrm{~cm}$ down to the core's bottom $\left(C_{2}\right)$. The reworked planktonic assemblages include some marker species from Zones N8-N10 such as Globorotalia peripheronda, Praeorbulina transitoria, P. sicana, P. glomerosa, among others. Late Cretaceous planktonic foraminifera (e.g., Contusotruncata fornicata and Globotruncana aegyptiaca) are very rare and poorly preserved throughout the entire Unit $C$ and one single specimen of the Upper Albian planktonic species Planomalina buxtorfi is found at around $45 \mathrm{~cm}$ b.s.f. ( $\mathrm{C}_{1}$; Fig. 7).

Shallow water benthic foraminifera such as Elphidium and Ammonia are generally rare and randomly distributed in this Unit. Remarkable is the presence of a few specimens of Bolboforma such as B. spinosa, B. compressispinosa, B. laevis and B. subfragoris (Fig. 8).

Pelagic sediments are found in the interval between 230 and $245 \mathrm{~cm}$ b.s.f. $\left(\mathrm{A}_{2}\right)$, where Holocene and recent fauna is relatively more abundant than in the hemipelagic layers overlying the mudbreccia at Dhaka and Maya MVs.

\subsection{Radiocarbon dating}

The mud-breccia intervals from the three MVs are associated with hemipelagic sediments that allow dating by AMS- ${ }^{14} \mathrm{C}$ on planktonic foraminifera. In particular at Dhaka MV the more recent breccia layer occurs between $4345 \pm 60$ and $4175 \pm 62$ cal. yr BP. At Maya MV the end of the more recent activity is dated as old as $15583 \pm$ 185 cal. yr BP. At Carmen MV the more recent, uppermost breccia layer occurs between $8998 \pm 59$ and $271 \pm 17$ cal. yr BP (Fig. 2, Table 2).

\section{Discussion}

\subsection{Stratigraphic succession underlying the mud volcanoes}

By comparing the seismic units of Jurado and Comas (1992) and Comas et al. (1996) and the sedimentary record cropping out in the Betic Neogene Basins (Rodríguez-Fernández et al., 1999) with the micropaleontological content of the mud-breccia from the three studied MVs (Fig. 3) it is possible to discriminate between elements from the olistostromic basal Unit VI (older than early Langhian; source layer sensu stricto) and from the overlying sedimentary sequence (younger than early Langhian). Furthermore, is possible to attribute discrete ages to the sedimentary sequences of the deep-seated breccias as follows (from older to younger):

Fig. 4. Range chart of the planktonic foraminiferal species identified at Dhaka MV. 1) Long-range Oligo-Miocene species; 2) Miocene species spanning the Aquitanian-Burdigalian; 3) long-range Oligocene to Pliocene species; $\mathrm{m}$ ) marker species of zones N8-N10 (Burdigalian pro parte-Langhian). Species abundance: $\mathrm{vr}=\mathrm{very}$ rare; $\mathrm{r}=\mathrm{rare} ; \mathrm{r} / \mathrm{c}=\mathrm{rare}$ to common; c $=$ common. Sample numbers represent depth from core's top. 


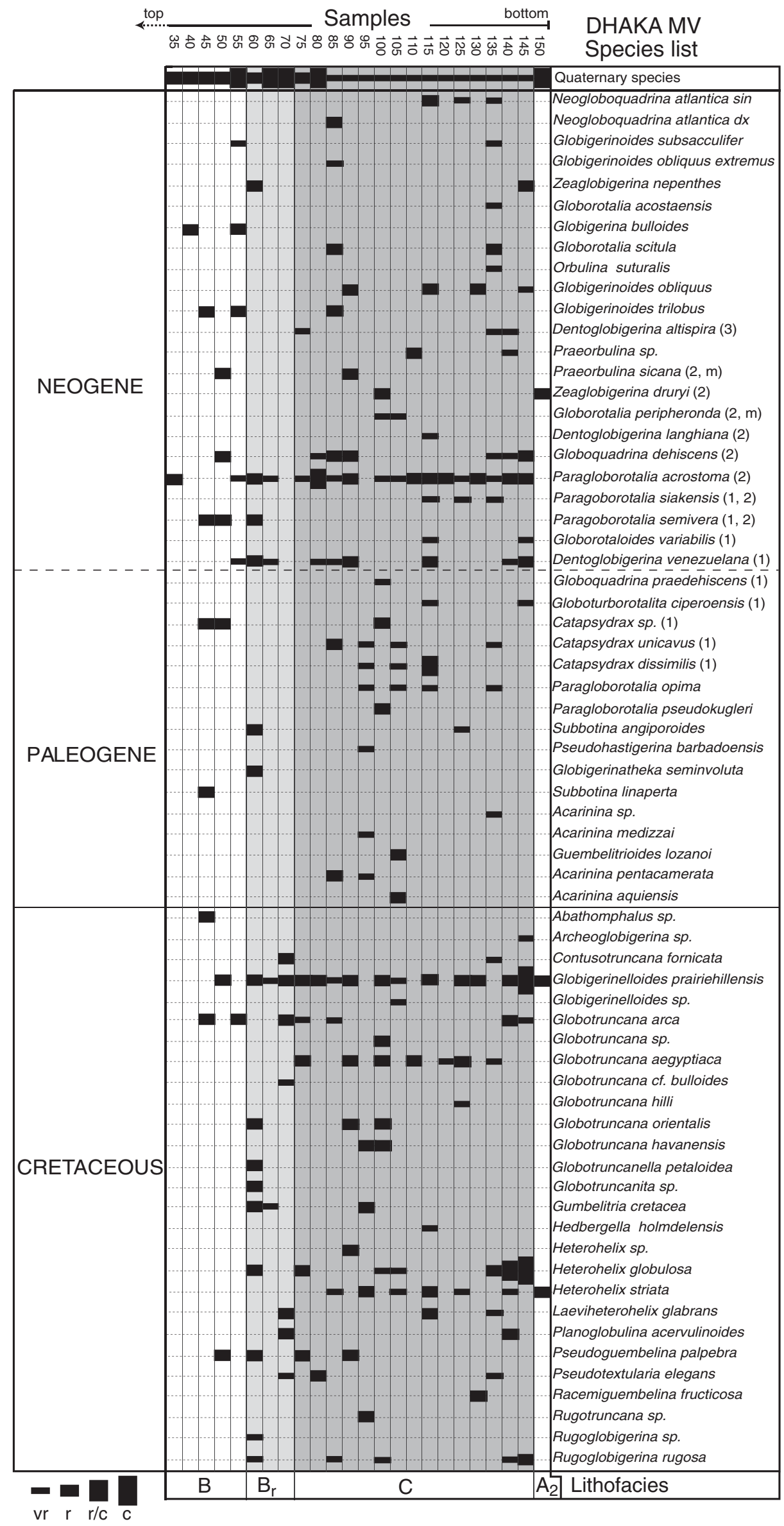




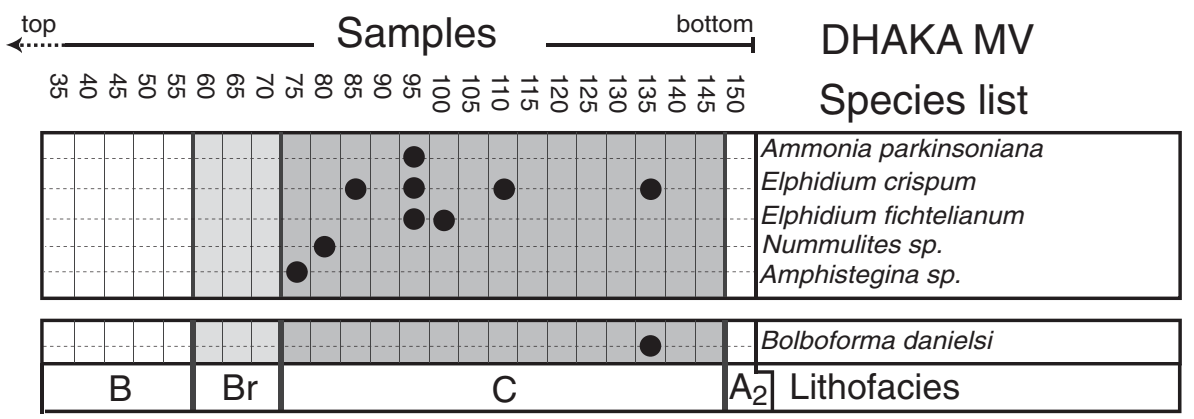

Fig. 5. Occurrence of shallow water benthic foraminifera and Bolboforma identified at Dhaka MV. Sample numbers represent depth from core's top.

\subsubsection{Mixed Late Cretaceous (Turonian to Maastrichtian) and Early Miocene - Unit VI (Fig. 3)}

Planktonic foraminiferal assemblages from the three investigated mud volcanoes confirm the previous attribution of the overpressured olistostromic unit to the Lower Miocene (Aquitanian - Burdigalian) with presence of reworked Upper Cretaceous, Paleocene and Eocene species (Sautkin et al., 2003). The occurrence of Oligocene planktonic species not identified before suggests that the olistostromes also contained sediments from this time interval.

A possible age analogue for the Aquitanian and Burdigalian sediments are the transgressive sediments outcropping in the Betic Rif Internal Zone, in particular their deeper depositional environment members (e.g., Ciudad Granada and Viñuela Fm; Serrano et al.,
2006). Reasonable analogues for Cretaceous sediments crop out in the Betic Cordillera (Martin-Chívelet and Chacón, 2007). The single specimen of Planomalina buxtorfi (Late Albian) found in the lowermost section of core MS385G (Carmen MV) may represent reworking of Albian species into Upper Cretaceous sediments. Good age and facies analogues for Paleocene and Eocene sediments are found in the Sub-Betic Zone (e.g., Molina et al., 1994) of the Betic Cordillera.

5.1.2. Middle to Late Miocene (Langhian to Late Tortonian) - seismic Units V, IV and III (Fig. 3)

Marine sediments deposited during this time interval vary from deep pelagic to shallow water. In the mud-breccia, sediments contain a mix of (pelagic) planktonic species from the base of Middle to Late
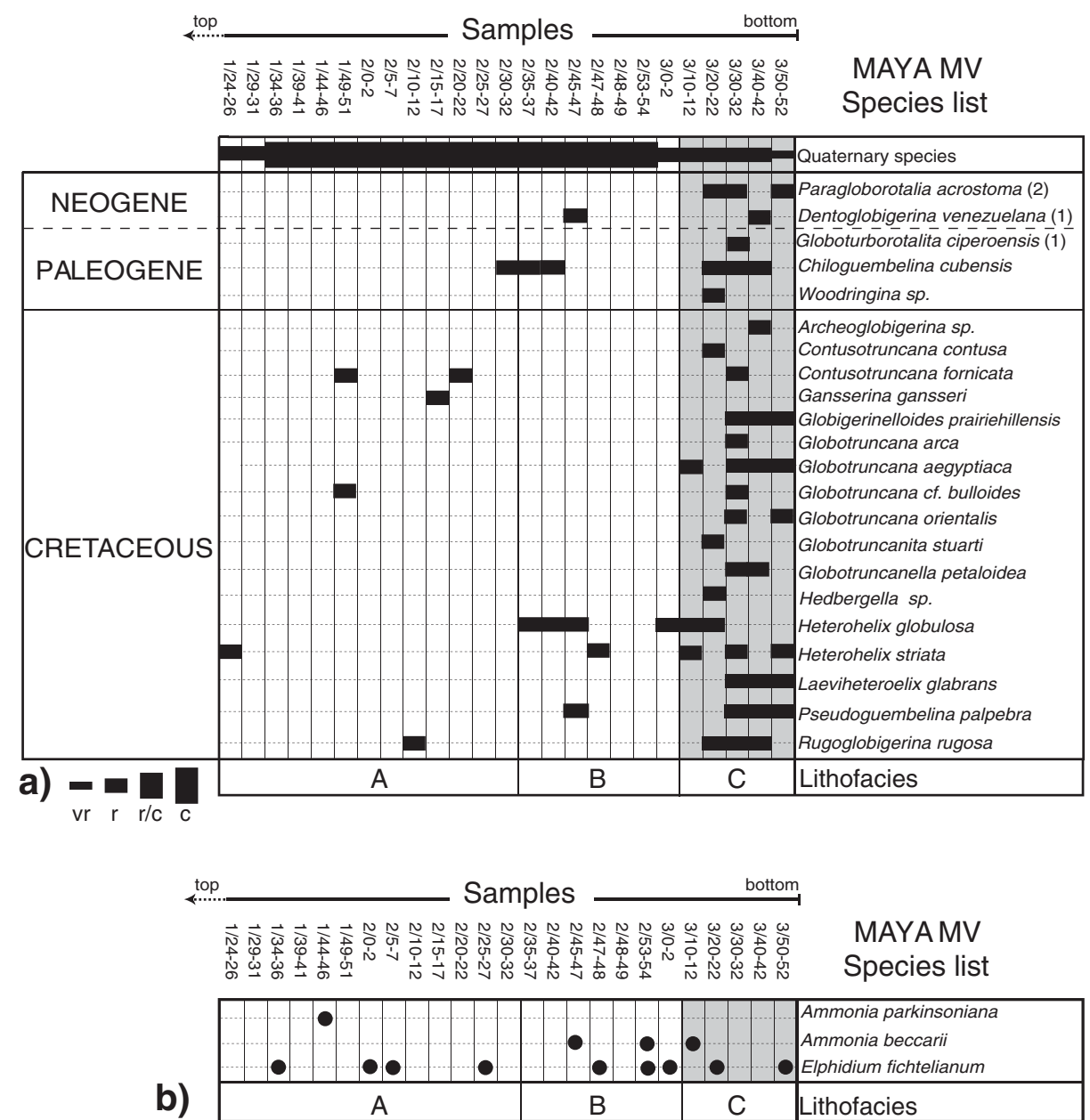

Fig. 6. a) Range chart of the planktonic foraminiferal species identified at Maya MV. 1) Long-range Oligo-Miocene species; 2) Miocene species spanning the Aquitanian-Burdigalian. Species abundance: $v r=$ very rare; $r=$ rare; $r / c=$ rare to common; $c=$ common. b) Occurrence of shallow water benthic foraminifera identified at Maya MV. Sample numbers represent depth from section's top (see Fig. 2 for samples' depth). 


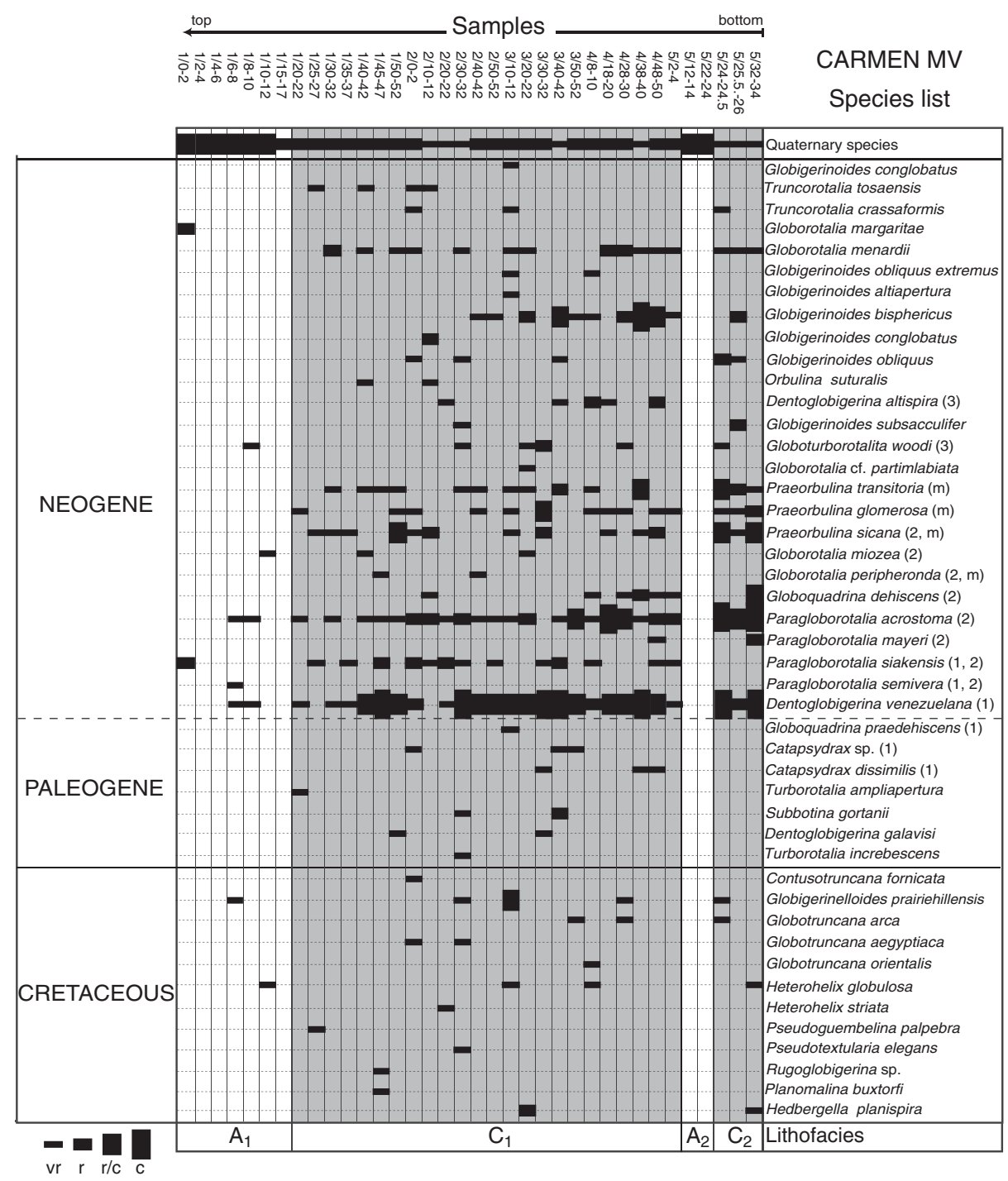

Fig. 7. Range chart of the planktonic foraminiferal species identified at Carmen MV. 1) Long-range Oligo-Miocene species; 2) Miocene species spanning the Aquitanian-Burdigalian; 3) long-range Oligocene to Pliocene species; $\mathrm{m}$ ) Marker species of Zones N8-N10 (Burdigalian pro parte-Langhian). Species abundance: $\mathrm{vr}=\mathrm{very}$ rare; $\mathrm{r}=\mathrm{rare} ; \mathrm{r} / \mathrm{c}=\mathrm{rare}$ to common; $\mathrm{c}=$ common. Sample numbers represent depth from section's top (see Fig. 2 for samples' depth).

Miocene. Since at ODP Site 976 few upper Miocene sediments were recovered (Messinian-Tortonian/Serravallian; Comas et al., 1996), the reference section for the Middle Miocene can be considered the one drilled at DSDP Site 372, yielding a complete succession of Langhian bioevents (Abdul Aziz et al., 2008). Bolboforma compressispinosa, $B$. laevis and B. subfragoris, which are abundantly present in Middle

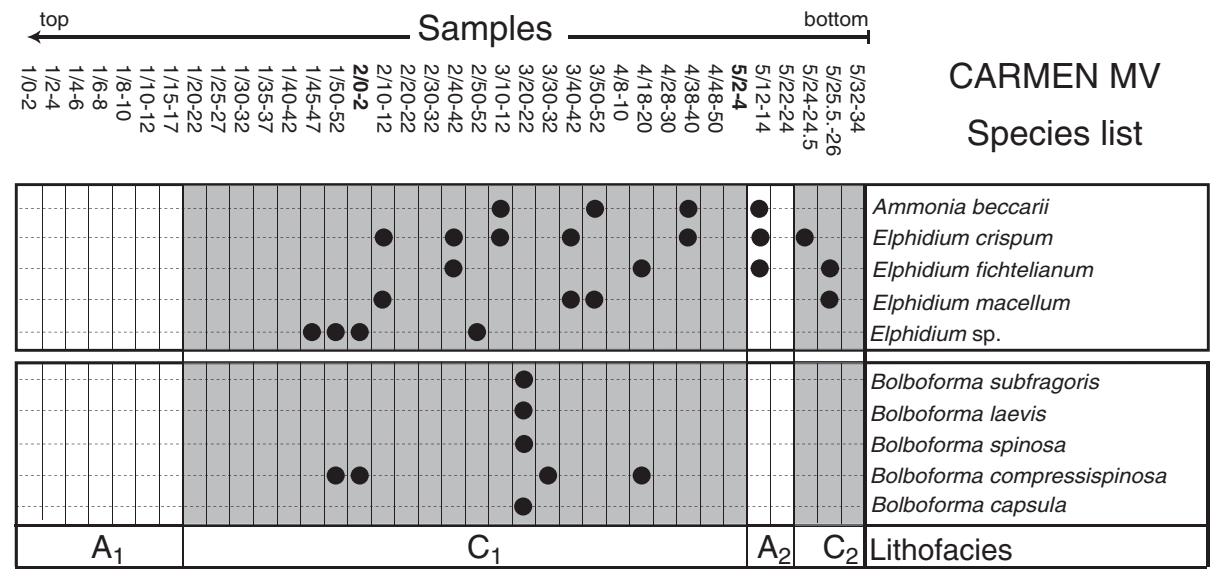

Fig. 8. Occurrence of shallow water benthic foraminifera and Bolboforma identified at Carmen MV. Sample numbers represent depth from section's top (see Fig. 2 for samples' depth). 
Stratigraphic distribution of selected taxa

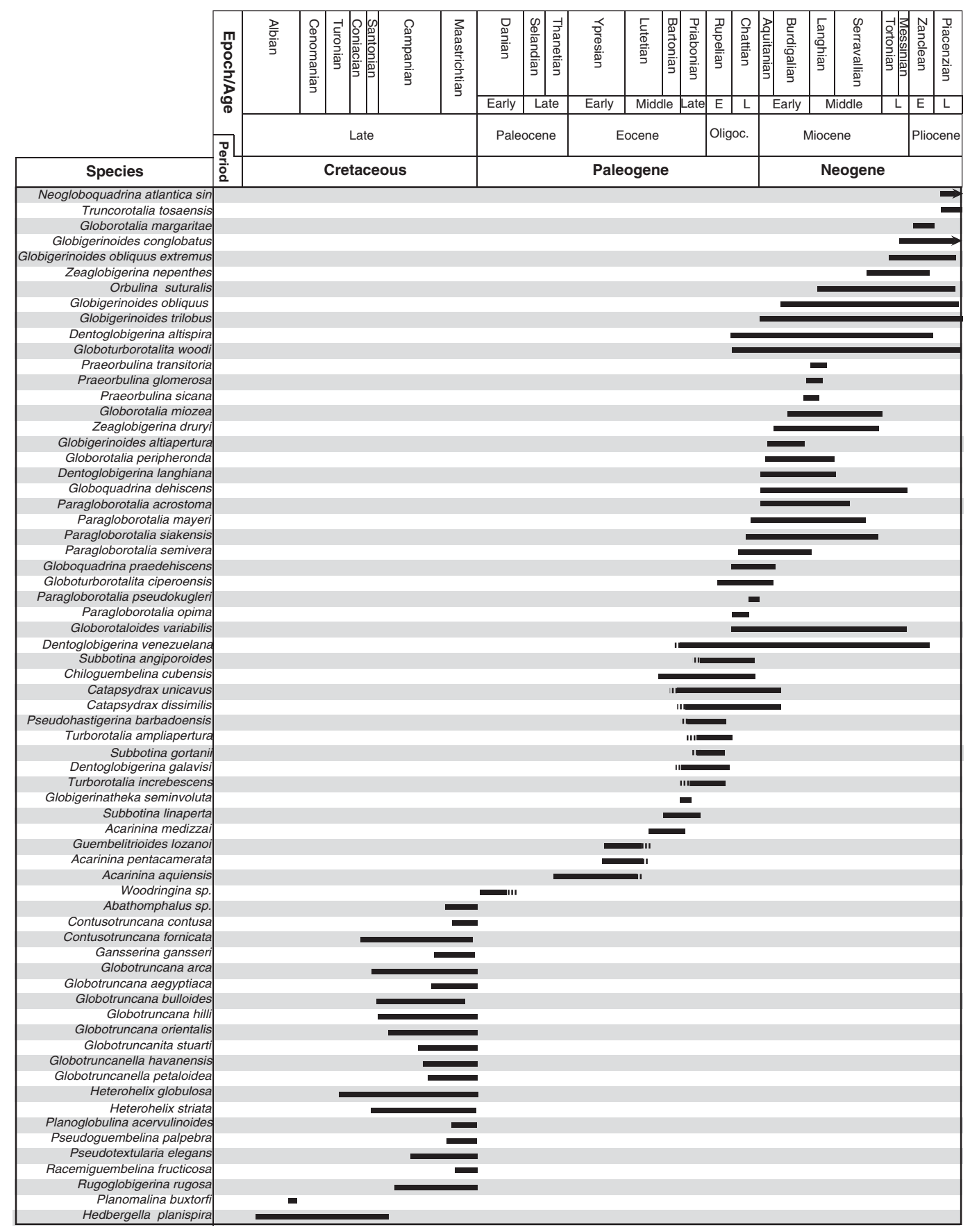

Fig. 9. Stratigraphic distribution of the species identified in the mud-breccia from the three studied MVs.

to Late Miocene successions of the Western Mediterranean Sea (Spezzaferri et al., 2001), are also recorded at Site 372 (Poag and Karowe, 1986). Their presence in the foraminiferal assemblages of the mud-breccia suggests a strict affinity with the sedimentary sequence of Site 372.

\subsubsection{Late Miocene (Messinian) - seismic Unit II (Fig. 3)}

Long-range shallow-water benthic foraminifera may be related to different sources such as the Messinian pre-evaporitic sedimentary sequence or the pelitic interbeds in the Messinian evaporitic unit. These sediments represent the most reasonable sources for the shallow benthic fauna which is very similar to that observed by Braga et al. (2006). Amphistegina sp. (Fig. 3 and Plate 8 (Supplementary Online Data), Fig. 5) may have also been associated to Messinian bioherms and reefs occurring in the outcropping Alboran marginal basins (e.g., Martín et al., 1999; Braga et al., 2006). Furthermore, shallow water depositional environments may have possibly occurred also on top of the structural highs and seamounts that characterize the complex Alboran Basin morphology (overview in Muñoz et al., 2008).

5.1.4. Pliocene to Pleistocene - seismic Unit I (Fig. 3)

The best reference for the sedimentary sequence spanning this interval has been cored during ODP Leg 161 at Site 976 located in the 
northwestern Alboran Basin (Comas et al., 1996). Sediments at this site consist of hemipelagic, turbidite, homogeneous gravity flow, contourite and debris flow facies (Alonso et al., 1999) characterized by the typical Pliocene to recent foraminiferal fauna.

\subsection{Source of extruded mud-breccias}

The micropaleontological study of mud breccias give direct, important information on the source layer, in particular in the case of deep-rooted mud volcanoes where the actual depth of the feeder channel is often difficult to detect in seismic lines, as is the case of some of the Alboran MVs (e.g., Carmen MV, Somoza et al., 2012). Furthermore, it allows identifying and differentiating elements from the two "sources" involved in mud-breccia extrusion: the source layer sensu stricto, and the overlying sedimentary sequence.

Our results, and in particular the occurrence of pre-Langhian species, confirm the basal olistostromic Unit VI as the main source of the extruded mud-breccias for the Dhaka, Maya and Carmen MVs, confirming previous interpretations based on micropaleontological and seismic studies (Sautkin et al., 2003; Talukder et al., 2003; Somoza et al., 2012). However, variations in the observed assemblages among the three studied sites suggest differences in the main source layer and in the plumbing systems underneath the MVs.

Sautkin et al. (2003) studied the Marrakech and Granada MVs from the southern region of the mud diapiric province in the West Alboran Sea. They discovered that, in both volcanoes, the mud-breccia consisted of well-consolidated, matrix-supported breccia with unconsolidated clasts. They also described the calcareous nannofossils and concluded that the source sediments derived from the overpressured olistostromic Unit VI and were Burdigalian in age (Early Miocene). These sediments contained Santonian and Maastrichtian, Paleocene and Eocene flora and incorporated Late Miocene to Pliocene elements from younger sediments during the extrusion of the erupted material. The mud-breccia from Dhaka and Carmen MVs is very similar in sedimentological and micropaleontological composition to Marrakech and Granada MVs and therefore a similar source layer (olistostromic Unit VI) can be assumed.

The mud-breccia from Maya MV contains dominant Santonian and Maastrichtian foraminifera and only a few relatively long-range Early Miocene specimens, thus lacking most of the species that characterize the basal Aquitanian - Burdigalian marine sediments containing the olistostromic deposits. According to Comas et al. (1999) the basal olistostromic Unit VI from Alboran contains significant amount of probably tectonically reworked Flysch Nappe Units from the Alboran Domain. Among these Flysch Units there are numerous allochthonous tectonic nappes of Late Cretaceous (Campanian-Maastrichtian) sediments. Sedimentary sequences of this age are well known and abundant in the Flysch Domain on land near the Algeciras region (e.g., Martínez del Olmo and Comas, 2008). Therefore, the olistostromic Unit VI contains allochtonous sediments of various ages and makes the source sediments rather dishomogeneous within the various Alboran mud volcanoes. In this context, Maya MV may be directly rooted in one of these olistoliths composed of Late Cretaceous Flysch.

Langhian and post-Langhian elements are well represented at Dhaka and Carmen MVs.

Seismic data suggests that Dhaka and Carmen MVs are fed by conduits deep-rooted in shale diapirs (Kenyon et al., 2003; Somoza et al., 2012; Comas et al., submitted for publication). According to Somoza et al. (2012), the feeder channel of Dhaka MV is composed by a feeder pipe connecting the seabed edifice to a buried bicone that may act as a pseudo-mud chamber. However, comparison of data from Dhaka and Carmen MVs suggest that the storage of deep source material at intermediate depths and its subsequent remobilization do not sensibly affect the original composition of the mud-breccia matrix.

At Maya MV, Langhian and post-Langhian species are extremely scarce or absent. This implies that sediments from the younger Unit V to I were not significantly incorporated into the ascending mud breccia. Maya MV may thus be rooted on a very shallow or outcropping mud diapir and lack any feeder channel, as already observed for MVs in the West Alboran (Somoza et al., 2003, 2012).

\subsection{Recent volcanic activity}

The presence of a relatively thick pelagic drape and cold-water coral rich layers on the top of the cores retrieved from the top of Dhaka and Maya MVs (60 cm and $115 \mathrm{~cm}$; Margreth et al., 2011), as well as their geochemical signature suggests that they are not presently active, or are dormant with only residual seep activity (Blinova et al., 2011).

The core retrieved from the flank of the Carmen MV presents only $20 \mathrm{~cm}$ of pelagic sediments. The strong smell of $\mathrm{H}_{2} \mathrm{~S}$ detected in the lower part of the core and the bubbling observed on the top of the volcano (e.g., Comas et al., 2010; Blinova et al., 2011) indicate that this structure may still be active today.

The activity of mud volcanoes in the Alboran Sea seems to be episodic as observed in other Mediterranean settings, e.g., the Mediterranean Ridge in the eastern basin (Robertson and Ocean Drilling Program Leg 160 Scientific Party, 1996; Robertson et al., 1998) and recurrent over timescales of thousands of year. Recent extrusive activity in the Southern MV Field started earlier than $16 \mathrm{ka} \mathrm{BP,} \mathrm{while} \mathrm{the} \mathrm{age}$ of the last extrusive episode differs among the studied MVs by thousands of years (from $>15.6$ ka at Maya to $>0.27$ ka at Carmen).

The duration of single mud erupting events is usually comprised between less than two days and few years (Mazzini et al., 2009 and references therein) and may thus be considered instantaneous over geological timescale. Our data support the hypothesis of very short-lived events, as observed at Dhaka MV where age uncertainties reduce the possible duration of the extrusive event to 50 years (170 \pm 120 yr; Table 2, Fig. 2).

Radiocarbon dating of the mud breccia layer extruded at Carmen shows a duration of mud-volcanic activity of thousand of years (Fig. 2). This can be explained either by extensive erosion of underlying hemipelagic sediment during mud-breccia flows or by the superimposition of different, erosive fluxes (i.e.; slumping) that flowed along the flank of Carmen MV earlier than $270 \mathrm{yr}$ BP. This latter hypothesis is corroborated by a) the position of the coring site, located on the flank of the mud-volcano, which may be more easily affected by sediment remobilization and b) by the lack of bioturbation in the underlying hemipelagic interval (i.e., absence of reworked planktonic foraminifera; Fig. 7) as a consequence of rapid accumulation.

\section{Conclusions}

The micropaleontological study of the mud-breccia matrix recovered from three Mud Volcanoes of the Western Alboran Mud Diapiric Province (Dhaka, Maya and Carmen MVs) shows that:

1) The main sediment source of the extruded mud-breccia is most likely identified in the lowermost overpressured olistostromic Unit VI that is Lower Miocene in age (Aquitanian-Burdigalian) and contains reworked Late Cretaceous, Paleocene and Eocene forms, confirming the previous attribution of Sautkin et al. (2003) for Marrakech and Granada MVs.

2) The mud-breccia matrix from Maya MV differs from that retrieved at both Dhaka and Carmen MVs (which in turn shows a close affinity to Marrakech and Granada MVs) in containing dominant Santonian-Maastrichtian foraminifera and fewer Early Miocene forms. Maya MV is probably directly rooted in one of the Late Cretaceous Flysch olistoliths present in the olistostromic Unit VI. Furthermore, the different distribution of foraminifera reworked from the younger sedimentary Units $\mathrm{V}$ to I suggests the possibility that the diapir feeding Maya MV may be very shallow. 
3) According to AMS- ${ }^{14} \mathrm{C}$ dating of hemipelagic sediments associated to the mud-breccia, mud volcanic activity in the Mud Diapiric Province seems to be episodic, short-lived and recurrent over thousands of years.

Supplementary data to this article can be found online at http:// dx.doi.org/10.1016/j.margeo.2013.04.002.

\section{Acknowledgments}

The authors gratefully acknowledge the Training Through Research Program (TTR) and the captain and crew of the R/V Professor Logachev (Moscow). Thanks also to Prof M. Ivanov (Moscow University) and his students for support and collaboration during the cruise. P. Grootes and M. Hüls from the Leibniz-Laboratory for Radiometric Dating are kindly acknowledged for AMS- ${ }^{14} \mathrm{C}$ dating. M. Caron is warmly thanked for helping in the determination of Cretaceous foraminifera. All scanning electron microscope (SEM) images were obtained at the Department of Geosciences, University of Fribourg.

This study was funded by the Swiss National Science Foundation Projects 200021-111694 and 200020-126367/1, with additional support from the Commission for Oceanography and Limnology of the Swiss Academy of Sciences to G.G. Cruise TTR-17 Leg 1 (SAGAS-08 Cruise) was funded by the Spanish Projects CTM 2009-077150 and CGL20803474 (R\&D National Plan of the Ministry of Economy and Competitivity, Spain) and by UNESCO. LMP participation was supported by GASALB project and the ESF EuroCORE-EuroMARGINS project MVSEIS (O1-LEC-EMA24F/PDCTM72003/DIV/40018). We thank D.J.W. Piper (Editor), D. Praeg and an anonymous reviewer for their constructive comments, which greatly improved the manuscript.

\section{References}

Abdul Aziz, H., Di Stefano, A., Foresi, L.M., Hilgen, F.J., Iaccarino, S.M., Kuiper, K.F., Lirer, F. Salvatorini, G., Turco, E., 2008. Integrated stratigraphy and ${ }^{40} \mathrm{Ar} /{ }^{39} \mathrm{Ar}$ chronology of early Middle Miocene sediments from DSDP Leg 42A, Site 372 (Western Mediterranean). Palaeogeography, Palaeoclimatology, Palaeoecology 257, 123-138.

Alonso, B., Ercilla, G., Martínez-Ruíz, F., Baraza, J., Galimont, A., 1999. Pliocene-Pleistocene sedimentary facies at Site 976. In: Zahn, R., Comas, M.C., Klaus, A. (Eds.), Depositional History in the Northwestern Alboran Sea. : Proceedings ODP, Scientific Results, 161. Ocean Drilling Program, College Station, TX, pp. 57-68.

Aslan, A., Warne, A.G., White, W.A., Guevara, E.H., Smyth, R.C., Raney, J.A., Gibeaut, J.C. 2001. Mud volcanoes of the Orinoco Delta, Eastern Venezuela. Geomorphology 41, 323-336.

Baraza, J.. Ercilla, G., 1996. Gas-charged sediments and large pockmark-like features on the Gulf of Cadiz slope (SW Spain). Marine and Petroleum Geology 13, 253-261.

Baraza, J., Ercilla, G., Nelson, C.H., 1999. Potential geologic hazards on the eastern Gulf of Cadiz slope (SW Spain). Marine Geology 155, 191-215.

Blinova, V.N., Comas, M.C., Ivanov, M.K., Poludetkina, E.N., Matveeva, T.V., 2011. Active mud volcanism in the West Alboran Basin: geochemical evidence of hydrocarbon seepage. Marine and Petroleum Geology 28, 1483-1504.

Braga, J.C., Martin, J.M., Riding, R., Aguirre, J., Sánchez-Almazo, I.M., Dinarès-Turell, J., 2006. Testing models for the Messinian salinity crisis: the Messinian record in Almería, SE Spain. Sedimentary Geology 188-189, 131-154.

Camerlenghi, A., Cita, M.B., Della Vedova, B., Fusi, N., Mirabile, L., Pellis, G., 1995. Geophysical evidence of mud diapirism on the Mediterranean Ridge accretionary complex. Marine Geophysical Research 17, 115-141.

Chapman, R.E., 1974. Clay diapirism and overthrust faulting. Geological Society of America Bulletin 85, 1597-1602.

Cita, M.B., Ryan, W.F.B., Paggi, L., 1981. Prometheus mud-breccia: an example of shale diapirism in the Western Mediterranean Ridge. Annales Géologiques des Pays Hélléniques 30, 543-570.

Comas, M.C., García-Dueñas, V., Jurado, M.J., 1992. Neogene tectonic evolution of the Alboran Sea from MCS data. Geo-Marine Letters 12,157-164.

Comas, M.C., Zahn, R., Klaus, A., et al., 1996. Proceedings ODP, Initial Report, 161. Ocean Drilling Program, College Station TX.

Comas, M.C., Platt, J.P., Soto, J.I., Watts, A.B., 1999. The origin and tectonic history of the Alboran Basin: insights from Leg 161 results. In: Zahn, R., Comas, M.C., Klaus, A. (Eds.), Proceedings ODP, Scientific Results, 161. Ocean Drilling Program, College Station, TX, pp. 555-580.

Comas, M.C., Soto, J.I., BASALCALB cruise (TTR-9 Leg 3) Scientific Party, 2000. A tectonic overview on the mud diapirs and related mud volcanoes in the Alboran Basin. Geological Processes on European Continental Margins (TTR-9 Post-Cruise Conference), Granada, Spain: IOC Workshop Report, 168, pp. 29-30.
Comas, M.C. Soto, J.I. Taludker, A.R., TTR-12 Leg 3 (MARSIBAL-1) Scientific Party, 2003a. Discovering active mud volcanoes in the Alboran Sea (Western Mediterranean). IOC Workshop Report, 187. UNESCO, pp. 14-16.

Comas, M.C., Talukder, A.R., Soto, J.I., 2003b. Mud volcanoes in the Alboran Sea: learning from occurrences in the western Mediterranean. Geophysical Research Abstracts 5, 12617.

Comas, M.C., Ivanov, M., TTR-14 Leg 3 Scientific Party, 2006. Geological and geophysical investigations of the Alboran Sea. In: Kenyon, N.H., Ivanov, M.K., Akhmetzhanov, A.M., Kozlova, E.V. (Eds.), Interdisciplinary geoscience studies of the Gulf of Cadiz and Western Mediterranean basin. : IOC Technical Series, 70. UNESCO, pp. 44-61.

Comas, M.C., Pinheiro, L.M., Ivanov, M.K., TTR-17 Scientific Party, 2010. The Alboran Sea Leg-1: look into mud volcanoes, carbonate mounds and climate Changes. IOC Technical Series, 94 8-64.

Comas, M.C., Suades, E., Crespo-Blanc, A., 2013. From mud diapirs to mud volcanoes: SHALE tectonics within the structural evolution of the Alboran Sea basin. Geotemas (submitted for publication)

Deville, E., Battani, A., Griboulard, R., Guerlais, S., Herbin, J.P., Houzay, J.P., Muller, C., Prinzhofer, A., 2003. The origin and processes of mud volcanism: new insights from Trinidad. In: Van Rensbergen, P., Hillis, R.R., Maltman, A.J., Morley, C.K. (Eds.), Subsurface Sediment Mobilization: Geological Society, London, Special Publications, vol. 216, pp. 475-490.

Deville, E., Guerlais, S.H., Lallemant, S., Schneider, F., 2010. Fluid dynamics and subsurface sediment mobilization processes: an overview from Southeast Caribbean. Basin Research 22, 361-379. http://dx.doi.org/10.1111/j.1365-2117.2010.00474.x.

Dewey, J.F., Helman, M.L., Turco, E., Hutton, D.W.H., Knott, S.D., 1989. Kinematics of the western Mediterranean. In: Coward, M.P., Dietrich, D., Park, R.G. (Eds.), Alpine Tectonics. Geological Society, London, Special Publications, 45, 265-283.

Dimitrov, L.I., 2002. Mud volcanoes - the most important pathway for degassing deeply buried sediments. Earth-Science Reviews 59, 49-76.

Dupré, S., Woodside, J., Foucher, J.-P., de Lange, G., Mascle, J., Boetius, A., Mastalerz, V. Stadnitskaia, A., Ondréas, H., Huguen, C., Harmegnies, F., Gontharet, S., Loncke, L., Deville, E., Niemann, H., Omoregie, E., Olu-Le Roy, K., Fiala-Medioni, A., Dählmann, A., Caprais, J.-C., Prinzhofer, A., Sibuet, M., Pierre, C., Sinninghe Damsté, J., NAUTINIL scientific Party, 2007. Seafloor geological studies above active gas chimneys off Egypt (Central Nile Deep Sea Fan). Deep Sea Research Part I 54, 1146-1172.

Faccenna, C., Piromallo, C., Crespo-Blanc, A., Jolivet, L., Rossetti, F., 2004. Lateral slab deformation and the origin of the western Mediterranean arcs. Tectonics 23, TC1012. http://dx.doi.org/10.1029/2002TC001488.

Fernández-Ibáñez, F., Soto, J.I., Zoback, M.D., Morales, J., 2007. Present-day stress field in the Gibraltar Arc (western Mediterranean). Journal of Geophysical Research 112, B08404. http://dx.doi.org/10.1029/2006JB004683.

Fernández-Puga, M.C., Vázquez, J.T., Somoza, L., Díaz del Rio, V., Medialdea, T., Mata, M.P., León, R., 2007. Gas-related morphologies and diapirism in the Gulf of Cadiz. Geo-Marine Letters 27, 213-221.

Fowler, S.R., Mildenhall, J., Zalova, S., Riley, G., Elsley, G., Desplanques, A., Guliyev, F. 2000. Mud volcanoes and structural development on Shah Deniz. Journal of Petroleum Science and Engineering 28, 189-206.

Frizon de Lamotte, D., Michard, A., Saddiqi, O., 2006. Quelques développements récents sur la géodinamique du Maghreb. Comptes Rendus Géoscience 338, 1-10.

García-Dueñas, V., Balanyá, J.C., Martínez-Martínez, J.M., 1992. Miocene extensional detachments in the outcropping basement of the northern Alboran Basin (Betics) and their tectonic implications. Geo-Marine Letters 12, 88-95.

Gardner, J.M., 2001. Mud volcanoes revealed and sampled on the western Moroccan continental margin. Geophysical Research Letters 28, 339-342.

Higgins, G.E., Saunders, J.B., 1974. Mud volcanoes - their nature and origin. Verhandlungen Naturforschende. Gesellschaft, Basel 84, 101-152.

Iaccarino, S. 1985. Mediterranean Miocene and Pliocene planktic foraminifera. In: Bolli, H.M., Saunders, J.B., Perch-Nielsen, K. (Eds.), Plankton Stratigraphy. Cambridge University Press, Cambridge, pp. 283-314.

Iaccarino, S.M. (Ed.), 2002. Integrated Stratigraphy and Paleoceanography of the Mediterranean Middle Miocene: Rivista Italiana Paleontologia e Stratigrafia, 108.

Ivanov, M.K., Kenyon, N.H., Nielsen, T., Wheeler, A., Monteiro, J., Gardner, J., Comas, M.C., Akhmanov, G.G., Akhmetzhanov, A.M., Scientific Party of the TTR-9 cruise, 2000. Goals and principal results of the TTR-9 cruise. Proceedings International Conference Geological Processes on European Continental Margins: IOC/UNESCO Workshop Report, 168, pp. 3-4.

Ivanov, M.K. Pinheiro, L.M., Stadnitskaia, A, Blinova, V, 2001. Hydrocarbon seeps on deep Portuguese margin. Final Proceedings 11th Meeting of the E.G.U., Strasbourg, France, CC11, p. 160.

Jurado, M.J., Comas, M.C., 1992. Well log interpretation and seismic character of the Cenozoic sequence in the northern Alboran Sea. Geo-Marine Letters 12, 129-136.

Kennett, J.P., Srinivasan, M.S., 1983. Neogene planktonic foraminifera. A Phylogenetic Atlas.Hutchinson Ross Publishing Company (265 pp.).

Kenyon, N.H., Ivanov, M.K., Akhmetzhanov, A.M., Akhmanov, G.G. (Eds.), 2000 Multidisciplinary study of geological processes on the North East Atlantic and Western Mediterranean Margins. : IOC Technical Series, 56. UNESCO.

Kenyon, N.H., Ivanov, M.K., Akhmetzhanov, A.M., Akhmanov, G.G. (Eds.), 2003. Interdisciplinary geoscience research on the North East Atlantic margin, Mediterranean Sea and Mid-Atlantic Ridge. : IOC Technical Series, 67. UNESCO.

Kenyon, N.H., Ivanov, M.K., Akhmetzhanov, A.M., Kozlova, E.V. (Eds.), 2006. Interdisciplinary geoscience studies of the Gulf of Cadiz and Western Mediterranean basins. : IOC Technical Series, 70. UNESCO.

Kohl, B., Roberts, B., 1994. Fossil foraminifera from four active mud volcanoes in the Gulf of Mexico. Geo-Marine Letters 14, 126-134.

Kopf, A.J., 2002. Significance of mud volcanism. Reviews of Geophysics 40, 1005. http:// dx.doi.org/10.1029/2000RG000093. 
Limonov, A.V., Dimitrov, L., Ivanov, M.K., Cifçi, G., Koktas, M., Felser, E., Huber, R., Gainanov, V., 1996. Mud volcanism and fluid venting in the eastern part of the Eastern Mediterranean Ridge. Initial Results of the Geological, Geophysical and Geochemical Investigations during the Fifth UNESCO-ESF "Training through Research" Cruise of R/V Logachev (July-September 1995): UNESCO Reports in Marine Science, 68 (173 pp.).

Loncke, L., Mascle, J., Fanil Scientific Parties, 2004. Mud volcanoes, gas chimneys, pockmarks and mounds in the Nile deep-sea fan (Eastern Mediterranean): geophysical evidences. Marine and Petroleum Geology 21, 669-689.

Magalhães, V., Pinheiro, L.M., Ivanov, M., Kozlova, E., Blinova, V., Kolganova, J., Vasconcelos, C., McKenzie, J.A., Bernasconi, S.M., Kopf, A., Diáz-del-Rio, V., González, F.J., Somoza, L., Gardner, J., 2012. Formation processes of methane-derived authigenic carbonates from the Gulf of Cadiz. Sedimentary Geology 243-244, 155-168.

Maldonado, A., Somoza, L., Pallarés, L., 1999. The Betic orogen and the Iberian-African boundary in the Gulf of Cadiz: geological evolution (central North Atlantic). Marine Geology 155, 9-43.

Margreth, S., Rüggeberg, A., Spezzaferri, S., 2009. Benthic foraminifera as bioindicators for cold-water coral ecosystems along the Irish margin. Deep Sea Research Part I $56,2216-2234$

Margreth, S., Gennari, G., Rüggeberg, A., Comas, M.C., Pinheiro, L.M., Spezzaferri, S., 2011. Growth and demise of cold-water coral ecosystems on mud volcanoes in the West Alboran Sea: the messages from the planktonic and benthic foraminifera. Marine Geology 282, 26-39.

Martín, J.M., Braga, J.C. Sánchez-Almazo, I., 1999. The Messinian record of the outcropping marginal Alboran basin deposits: significance and implication. In: Zahn, R. Comas, M.C., Klaus, A. (Eds.), Proceeding ODP, Scientific Results, 161. Ocean Drilling Program, College Station, TX, pp. 543-551.

Martin-Chívelet, J., Chacón, B., 2007. Event stratigraphy of the upper Cretaceous to lower Eocene hemipelagic sequences of the Prebetic Zone (SE Spain): record of the onset of tectonic convergence in a passive continental margin. Sedimentary Geology 197, 141-163.

Martínez del Olmo, W., Comas, M.C., 2008. Arquitectura sismica, olistostromas y fallas extensionales en el norte de la cuenca oeste del Mar de Alborán. Revista de la Sociedad Geológica de España 21, 151-167.

Mazurenko, L.L., Soloviev, V.A., Belenkaya, I., Ivanov, M.K., Pinheiro, L.M., 2002. Mud volcano gas hydrates in the Gulf of Cadiz. Terra Nova 14, 321-329.

Mazzini, A., Svensen, H., Planke, S., Guliyev, I., Akhmanov, G.G., Fallik, T., Banks, D., 2009. When mud volcanoes sleep: insight from seep geochemistry at the Dashgil mud volcano, Azerbaijan. Marine and Petroleum Geology. http://dx.doi.org/ 10.1016/j.marpetgeo.2008.11.003.

Molina, E., Canudo, J.I., Martínez, F., Ortiz, N., 1994. Integrated stratigraphy across the Paleocene/Eocene boundary at Caravaca, southern Spain. Eclogae Geologicae Helvetiae 87, 47-61.

Muñoz, A., Ballesteros, M., Montoya, I., Rivera, J., Acosta, J., Uchupi, E., 2008. Alborán Basin, southern Spain - part i: geomorphology. Marine and Petroleum Geology 25, 59-73.

Pearson, P.N., Olsson, R.K., Huber, B.T., Hemleben, C., Berggren, W.A. (Eds.), 2006. Atlas of Eocene Planktonic Foraminifera: Cushman Foundation Special Publication, 41 (514 pp.).

Pinheiro, L.M., Ivanov, M.K., Sautkin, A., Akhmanov, G., Magalhães, V.H., Volkonskaya, A., Monteiro, J.H., Somoza, L., Gardner, J., Hamouni, N., Cunha, M.R., 2003. Mud volcanism in the Gulf of Cadiz: results from the TTR-10 cruise. Marine Geology 195, 131-151.

Pinheiro, L.M., Ivanov, M.K., Kenyon, N.H., Magalhães, V., Somoza, L., Gardner, J., Kopf, A., Van Rensbergen, P., Monteiro, J.H., Euromargins-MVSEIS Team, 2006. Structural control of mud volcanism and hydrocarbon-rich fluid seepage in the Gulf of Cadiz: results from the TTR-15 and other previous cruises. In: Mascle, J., Sakellariou, D., Briand, F. (Eds.), Fluid Seepages/Mud Volcanism in the Mediterranean and Adjacent Domains: CIESM Workshop Monographs, 29, CIESM, Bologna, Italy, pp. 53-58.

Poag, C.W., Karowe, A.L., 1986. Stratigraphic potential of Bolboforma significantly increased by new finds in the North Atlantic and South Pacific. Palaios 1, 162-171.

Praeg, D., Svensen, H., Hovland, M., Banks, D.A., Jamtveit, B., 2003. Mud and fluid migration in active mud volcanoes in Azerbaijan. Geo-Marine Letters 23, 258-268

Praeg, D., Ceramicola, S., Barbieri, R., Unnithan, V., Wardell, N., 2009. Tectonically-driven mud volcanism since the late Pliocene on the Calabrian accretionary prism, central Mediterranean Sea. Marine and Petroleum Geology 26, 1849-1865. http://dx.doi.org/ 10.1016/j.marpetgeo.2009.03.008.

Premoli Silva, I., Verga, D., 2004. Practical manual of Cretaceous planktonic foraminifera. In: Verga, D., Rettori, R. (Eds.), International School on Planktonic Foraminifera, 3rd Course: Cretaceous. Universities of Perugia and Milan (283 pp.).
Premoli Silva, I., Erba, E., Spezzaferri, S., Cita, M.B., 1996. Age variation in the source of the diapiric mud breccia along and across the axis of the Mediterranean Ridge Accretionary Complex. Marine Geology 132, 175-202.

Premoli Silva, I., Rettori, R., Verga, D., 2003. Practical manual of Paleocene and Eocene planktonic foraminifera. In: Rettori, R., Verga, D. (Eds.), International School on Planktonic Foraminifera, 2nd Course: Paleocene and Eocene. Universities of Perugia and Milan (152 pp.).

Robertson, A., Ocean Drilling Program Leg 160 Scientific Party, 1996. Mud volcanism on the Mediterranean Ridge: initial results of Ocean Drilling Program Leg 160. Geology 24, 239-242.

Robertson, A.H.F., Emeis, K.-C., Richter, C., Blanc-Valleron, M.-M., Bouloubassi, I., Brumsack, H.-J., Cramp, A., Di Stefano, G.J., Flecker, R., Frankel, E., Howell, M.W., Janecek, T.R., Jurado, M.-J., Kemp, A.E.S., Koizumi, I., Kopf, A., Major, C.O., Mart, Y., Pribnow, D.F.C. Rabaute, A., Roberts, A.P., Rullkotter, J.H., Sakamoto, T., Spezzaferri, S., Staerker, T.S., Stoner, J.S., Whiting, B.M., Woodside, J., 1998. Collision-related break-up of a carbonate platform (Eratosthenes Seamount) and mud volcanism on the Mediterranean Ridge: preliminary synthesis and implication of tectonic results of ODP Leg 160 in the Eastern Mediterranean Sea. In: Cramp, A., MacLeod, C.J., Lee, S.V., Jones, E.J.W. (Eds.), Geological Evolution of Ocean Basins: results from the Ocean Drilling Program. Geological Society, London, Special Publications, 131, pp. 243-271.

Rodríguez-Fernández, J., Comas, M.C., Soría, J., Martín-Pérez, J.A., Soto, J.I., 1999. The sedimentary record of the Alboran Basin: an attempt at sedimentary sequence correlation and subsidence analysis. In: Zahn, R., Comas, M.C., Klaus, A. (Eds.), Proceedings ODP, Scientific Results, 161. Ocean Drilling Program, College Station, TX, pp. 69-76.

Sautkin, A., Talukder, A.R., Comas, M.C., Soto, J.I., Alekseev, A., 2003. Mud volcanoes in the Alboran Sea: evidence from micropaleontological and geophysical data. Marine Geology 195, 237-261.

Serrano, F., Sanz de Galdeano, C., El Kadiri, K., Guerra-Merchán, A., López-Garrido, A.C., Martín-Martín, M., Hlila, R., 2006. Oligocene-early Miocene transgressive cover of the Betic-Rif Internal Zone. Revision of its geological significance. Eclogae Geologicae Helvetiae 99, 237-253.

Siani, G., Paterne, M., Arnold, M., Bard, E., Métivier, B., Tisnerat, N., Bassinot, F., 2000. Radiocarbon reservoir ages in the Mediterranean Sea and Black Sea. Radiocarbon 42, 271-280.

Somoza, L., Ivanov, M.K., Pinheiro, L.M., Maestro, A., Lowrie, A., Vázquez, J.T., Gardner, J. León, R., Fernández-Puga, M.C., 2000. Structural and tectonic control of fluid seeps and mud volcanoes in the Gulf of Cadiz. Proceedings of the TTR-10 Post-Cruise Meeting, Mozenka, Moscow.

Somoza, L., Díaz-del-Rio, V., León, R., Ivanov, M.K., Fernández-Puga, M.C., Gardner, J.M. Hernández-Molina, F.J., Pinheiro, L.M., Rodero, J., Lobato, A., Maestro, A., Vázquez, J.T., Medialdea, T., Fernández-Salas, L.M., 2003. Seabed morphology and hydrocarbon seepage in the Gulf of Cádiz mud volcano area: acoustic imagery, multibeam and ultra-high resolution seismic data. Marine Geology 195, 153-176.

Somoza, L., Medialdea, T., León, R., Ercilla, G., Vázquez, J.T., Farran, M., HernándezMolina, J., González, J., Juan, C., Fernández-Puga, M.C., 2012. Structure of mud volcano systems and pockmarks in the region of the Ceuta Contourite Depositional System (Western Alborán Sea). Marine Geology 332-334, 4-26.

Spezzaferri, S., 1994. Planktonic foraminiferal biostratigraphy and taxonomy of the Oligocene and lower Miocene in the oceanic record. An overview. Paleontographia Italica 81, 1-187.

Spezzaferri, S., Mutti, M., Spiegler, D., 2001. Integrated planktonic foraminifera, Bolboforma and carbon isotope stratigraphy in a mid/early late Miocene carbonate ramp setting from the Acreide area (Sicily). Marine Micropaleontology 43, 223-238.

Sprovieri, R., Bonomo, S., Caruso, A., Di Stefano, A., Di Stefano, E., Foresi, L.M., Iaccarino, S., Lirer, F., Mazzei, R., Salvatorini, G., 2002. An integrated calcareous plankton biostratigraphic scheme and biochronology for the Mediterranean Middle Miocene. Rivista Italiana di Paleontologia e Stratigrafia 108, 337-353.

Staffini, F., Spezzaferri, S., Aghib, F., 1993. Mud diapirs of the Mediterranean Ridge: sedimentological and micropaleontological study of the mud breccia. Rivista Italiana di Paleontologia e Stratigrafia 99, 225-254.

Stuiver, M., Reimer, P.J., 1993. Extended ${ }^{14} \mathrm{C}$ data base and revised Calib $3.0{ }^{14} \mathrm{C}$ age calibration program. Radiocarbon 35, 215-230.

Talukder, A.R., 2003. La provincia diapírica de lodo en la Cuenca Oeste del Mar de Alborán: estructuras, génesis y evolución. Unpublished PhD Thesis Universidad de Granada (251 pp.).

Talukder, A.R., Comas, M.C. Soto, J.I. 2003. Pliocene to recent mud diapirism and related mud volcanoes in the Alboran Sea (Western Mediterranean). In: Van Rensbergen, P., Hillis, R.R., Maltman, A.J., Morley, C.K. (Eds.), Subsurface Sediment Mobilization. Geological Society, London, Special Publications, 216, pp. 443-459. 